\title{
Jagad Jawa RM Kristiadi pada Proses Kreatif Program Televisi di TVRI Yogyakarta
}

\author{
Titus Soepono Adji \\ Program Studi Film dan Televisi, Fakultas Seni Rupa dan Desain \\ Institut Seni Indonesia (ISI) Surakarta \\ tusjik123@gmail.com
}

\begin{abstract}
RM Kristiadi is a TV producer at TVRI who has been working since 1997. He is involved in programs that still exist at TVRI Yogyakarta, such as Obrolan Angkringan, Plengkung Gading, Karang Tumaritis, etc. These programs stil exist until right now, among others, because they lift the atmosphere of Javanese Culture in accordance with the principle of the similarity of body memory, the framework of fantasy that is believed in the process of its creation. RM Kristiadi also conducted experiments in building new works through critical thinking on the achievements that have ever existed. This research is a qualitative descriptive study, which focuses on knowing the background of RM Kristiadi's creative process. Data was collected through a series of direct interview processes with the interviewees, with data reinforced from documents.
\end{abstract}

Key Word: Java Athmosphere, TV Produser, TV Program.

Pendahuluan

Program televisi memiliki tiga fungsi, yaitu informasi, hiburan dan edukasi. (Morisan, 2013: 210). Untuk memenuhi fungsi-fungsi tersebut, setiap program televisi harus dirancang sesuai dengan tujuannya. Dalam penciptaan program televisi, secara umum Pengarah Acara, atau Program Director, jauh lebih dikenal daripada peran seorang Perancang Acara. Padahal dalam perencanaan program televisi, konten maupun perangkat teknis produksi, direncanakan oleh perancang acara, sehingga sangat menentukan hasil akhir program tersebut. Fungsi keperancangan acara ini dilaksanakan oleh seorang produser. Produser sendiri sebetulnya memiliki beberapa pengertian yang sangat luas, antara lain, seperti menurut Jonathan Bignell (2004:99), orang yang bertanggung jawab mulai anggaran, perencanaan dan terlibat dalam pembuatan program televisi atau serangkaian program televisi.

Dalam buku Producing TV and Vid- eo, tulisan Chatrine Elison (2006:4), yang memiliki bab khusus membahas produser pun tidak memberi batasan kerja produser. Produser digambarkan sebagai manusia super.

Without a producer, there is no project. The producer propels the project from an unformed idea to living-color broadcast. He can nurture the project from conception to distribution and might also be the writer, director, or the financing source. At various stages of production, he may bring in other producers who can help in handling the hundreds of details that need supervision or polish

The producer is the first one on a project and the last one off, essentially the overall project supervisor who gets it off the ground, and then supervises every step of its development and production.

Produser yang memiliki medan kerja sangat luas, menurut Garth Drabinsky dalam Johnson (2002:57), berperan sebagai katalisator yang bertanggung jawab pada masalah pem- 
biayaan, kreatifitas sekaligus elemen teknis produksi. Jadi tidak hanya sekadar biaya dan teknis, dalam hal ini kreatifitas menjadi poin utama yang akan menentukan sebesar apa kontribusi finansial jika keuntungan dijadikan parameter kesuksesan film.

Dalam fungsi sebagai perencana inilah secara konseptual, ide dikembangkan menjadi konsep atas arahan seorang produser sebagai perancang acara. Dalam posisi ini seorang produser berkedudukan pula sebagai seniman. Jika film dianggap sebagai kanvas dari sutradara, maka program televisi adalah layar milik produser. Namun demikian, selain hal-hal di dalam produksi, produser juga harus memiliki jembatan pemahaman yang sama dengan khalayak pemirsa. Hal ini penting, karena program televisi dihadirkan sebagai penyampai pesan yang menarik bagi khalayaknya.

RM Kristiadi adalah seorang produser di TVRI Stasiun Yogyakarta, sejak tahun 1997. Dari tangannyalah antara lain kemudian khalayak Yogyakarta, Jawa Tengah dan sekitarnya mengenal program Obrolan Angkringan, Wayang-Wayang Kertas, Karang Tumaritis, Plengkung Gading, Beteng Rotterdam dan sebagainya. Program-program besutannya sangat unik, karena selain sesuai dengan ciri lokalitas, mengangkat atmosferik Jagad Jawa yang kental, juga kebanyakan program-program tersebut masih eksis.

Jagad Jawa menjadi diksi penting dalam melihat karya-karya RM Kristiadi, karena mengangkat elemen-elemen budaya Jawa yang kental, antara lain bahasa Jawa, artistik maupun musik. Elemen-elemen tersebut tak dapat dilepaskan dari pengalaman estetik RM Kristiadi yang sejak lahir hidup dalam ruang kebudayaan Jawa yang kental, yaitu lingkungan Kraton Ngayogyakarta Hadiningrat.

Masyarakat Jawa memandang Jagadnya terimplementasi dalam 2 hal, yaitu Jagad Cilik dan Jagad Gede. Jagad cilik atau disebut juga mikrokosmos, merupakan jagad manusia. Sedangkan jagad gede atau makrokosmos adalah berkaitan dengan alam dimana manusia berada. Jagad cilik memiliki dimensi sosial, sedangkan jagad gede memiliki dimensi spiritual. (Darmoko, 2002:30)

Hubungan keduanya tidak selalu dalam situasi harmonis atau stabil, melainkan saling mempengaruhi. Jika terjadi situasi disharmoni di antara keduanya, manusia melakukan upaya-upaya untuk mengatasinya, yaitu ruwatan. Dalam pemahaman kreatifitas seni, jagad juga bisa dimaknai sebagai ruang atau atmosfer di mana seniman hidup dan berkarya, ketika ruang ini mengalami suasana disharmoni muncul juga upaya meruwat melalui konsep-konsep kreatif yang khas. Pertanyaan yang kemudian berkait dengan fenomena tersebut adalah bagaimana sebenarnya RM Kristiadi memperoleh bekal Jagad Jawa dalam dirinya, menjaganya saat berkarir, dan mengimplementasikannya di layar televisi sehingga mampu terjaga eksistensinya.

Penelitian ini merupakan penelitian Deskriptif Kualitatif dengan mengangkat subyek RM Kristiadi sebagai narasumber penelitian. Metode pengumpulan data dilakukan dengan wawancara mendalam dengan fokus dalam 2 hal, yaitu pengalaman estetik di masa muda RM Kristiadi berdasarkan lingkungan atmosferik keseniannya, serta proses kreatif yang dilakukan oleh R Kristiadi saat berkarya di TVRI Yogyakarta. Dari sekian banyak program yang digarap RM Kristiadi, penelitian ini akan memfokuskan pada 2 program yaitu Obrolan Angkringan sebagai program pertama besutannya yang masih tayang, dan Beteng Rotterdam, sebagai program terakhir yang dibesutnya sebagai supervisi produksi. Pada bagian akhir dikonfirmasikan hubungan pengaruh pengalaman estetik di masa muda dengan proses kreatif yang dilakukan pada proses berkaryanya saat ini, terutama dalam layar televisi. 


\section{Asintya}

Jurnal Penelitian Seni Budaya

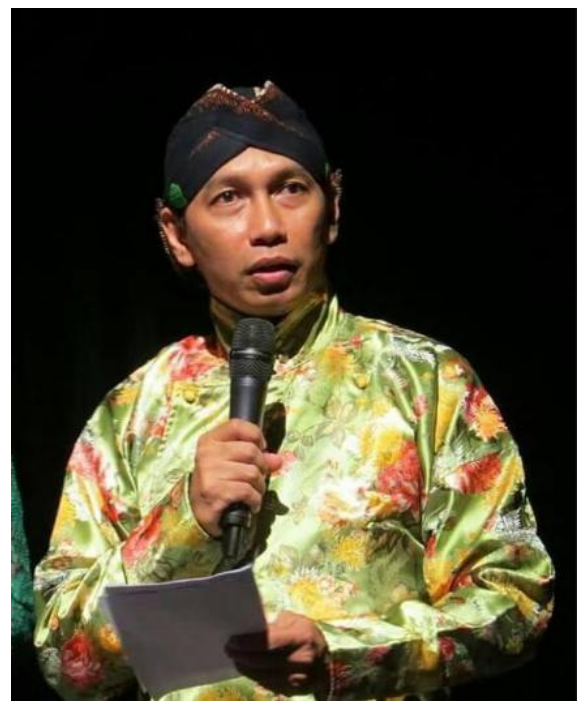

RM Kristiadi

(Sumber: Koleksi RM Kristiadi)

\section{B. Pembahasan}

\section{RM Kristiadi dan Masa Kecilnya}

RM Kristiadi adalah seorang produser program televisi di TVRI Yogyakarta.

Dari sentuhan kreatifitasnya, TVRI Yogyakarta, sejak tahun 1997 turut melahirkan karya-karya perancangan seperti Obrolan Angkring, Taman Gabusan, Plengkung Gading, Karang Tumaritis, Slemana Sembada, WayangWayang Kertas, Kuncung Bawuk Reborn dan Beteng Rotterdam (ketoprak televisi yang menceritakan perjuangan masyarakat pada masa pengasingan Pangeran Diponegoro di Makassar).

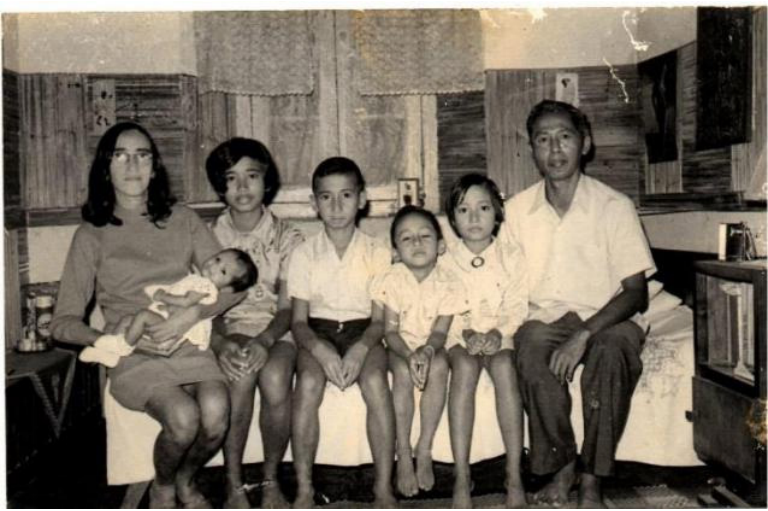

RM Kristiadi (tengah) dan keluarga di masa kecil (sumber;dokumen keluarga)
Ia lahir di Yogyakarta, 3 Maret 1966, dan besar di lingkungan keraton Yogyakarta, tepatnya di nDalem Mangkubumen, sebagai bangsawan di lingkungan Keraton Kasultanan Ngayogyakarta Hadiningrat. RM Kristiadi adalah buyut dari Sri Sultan Hamengku Buwono VIII, putra pasangan Raden Muso Husodo dengan ibu Raden Ayu Siti Kadirun.

Tinggal di lingkungan keraton membuat masa kecilnya sudah akrab dengan suara gamelan dan tarian, yang mengisi hari-harinya sejak kecil dan membuatnya tumbuh sebagai penari, di bawah asuhab nenek, GRA Sindoerdjo, dan pamannya, RM Dinusatomo (KPH Pujaningrat), yang mengasuh sanggar tari di lingkungan nDalem Mangkubumen. RM Kristiadi sendiri tidak mengingat kapan pertama kali naik pentas untuk menari. Yang diingat adalah saat itu sang nenek, GRA Sindoerjo, memberikan sepotong selendang sebagai hadiah pementasan. Memori itu diingat betul oleh Kristiadi, dan menjadi motivasi utama menekuni tarian hingga saat ini.

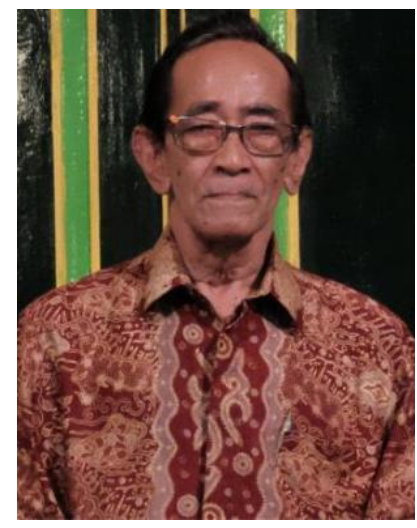

RM Dinusatomo, Guru dan Paman RM Kristiadi (Sumber: https://siswaamongbeksa.wordpress. com)

Saat Sekolah Dasar RM Kristiadi yang bersekolah di SD Keputran, acap mengikuti perlombaan tari, dan kerap kali pula mendulang juara. Rupanya minat seni Kristiadi tidak hanya menari; ia juga mengumpulkan teman-temannya di kampung untuk bermain ketoprak-ketoprakan.

Beranjak usia SMP, bakat kesenian RM Kristiadi semakin membutuhkan tantangan. Ketertarikannya membuat grup lawak 
dan ketoprak ini tak lepas dari kegemarannya menyaksikan wayang orang dan ketoprak. RM Kristiadi kerap diajak eyangnya untuk menonton pementasan wayang orang di Sriwedari, Solo, maupun Ketoprak Siswa Budaya. Akibat sering melakukan pentas tari, lawak dan ketoprak tersebut, ia diterima masuk ke sebuah SMA swasta favorit tanpa tes. Namun begitu tawaran itu tidak diterimanya. RM Kristiadi merasa tidak mampu memenuhi tuntutan prestasi akademik dengan baik. Ia lebih suka menari dan membuat karya seni pertunjukan.

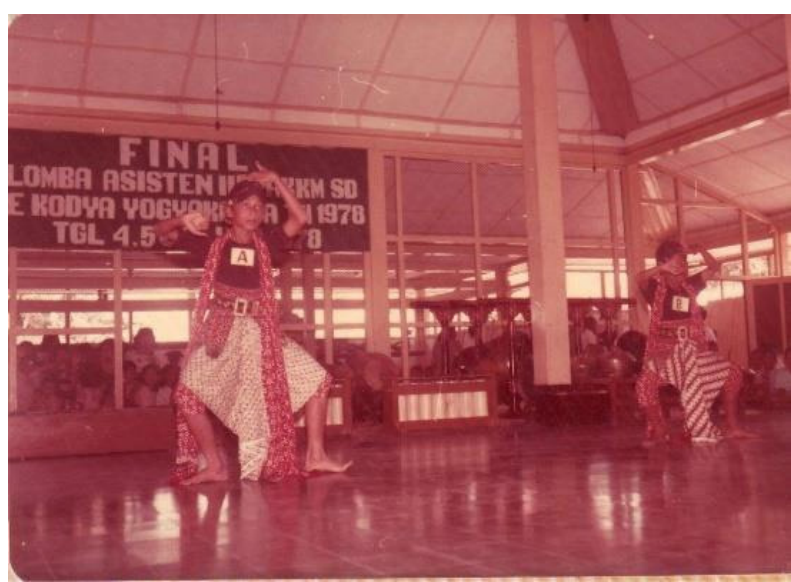

RM Kristiadi muda dalam sebuah Final Lomba Tari (Sumber: Koleksi Kristadi)

Selepas SMP, RM Kristiadi bersekolah di SMA Bopkri 1. Di sekolah ini geliat seni RM Kristiadi tidak berhenti. Ia membentuk sebuah kelompok tari bernama Oratorium Parakumara. Oratorium ini adalah format yang populer saat itu; pertunjukan tari dan teater yang disajikan secara musikal dengan mengangkat cerita sosio drama.

"Pertama saya membuat ketoprak di student rileks. Ajang Siswa tampil, dan gagal. Penonton nggak mau lihat. Terus setelah itu saya buat ketoprak dengan musik play back di acara tutup tahun. Biar anak muda seneng saya buat bukan dengan nama ketoprak, tapi Oratorium" (wawancara 25 Oktober 2019)

Pertunjukan ini kemudian sangat disukai oleh para siswa dan kemudian menjadi kelompok yang sangat fenomenal di sekolahnya. Pada masanya, kelompok ini pernah beranggotakan 300 orang peserta. Bersama Oratorium Parakumara, RM Kristiadi membuat beberapa lakon, yaitu Ranggalawe, Ramayana dan Rorojonggrang. Untuk latihan para siswa bermarkas di rumahnya, di nDalem Mangkubumen, yang memiliki halaman luas.

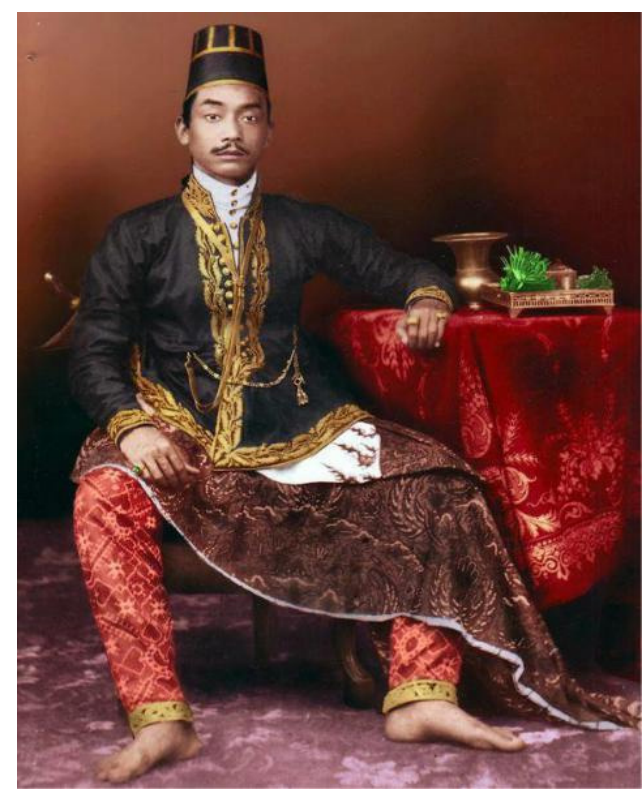

KGPAA Mangkubumi (Koleksi: RM Kristiadi)

Dalem Mangkubumen adalah sebuah kompleks rumah bangsawan, yaitu KGPAA Mangkubumi (adik Kanjeng Sultan Hamengkubuwono VIII). Terletak di sebelah barat Taman Sari Kraton. Dalem Mangkubumen menurut RM Kristiadi, memiliki tingkatan kluster kedua di bawah Keraton. Di dalamnya ada ruang Proboyekso, yaitu tempat menyimpan pusaka keraton. Dalem ini juga memiliki tipologi arsitektural menyerupai kompleks kraton, bahkan kompleks ini memiliki situs miniatur taman sari, yaitu kolam petirtaan.

Sebagaimana di masa awal kemerdekaan kraton menjadi tempat embrio kampus-kampus berkembang (seperti UGM, ASRI dan Asdrafi), saat ini di Dalem Mangkubumen bahkan masih aktif digunakan sebagai kampus, yaitu Universitas Widya Mataram. Di Dalem tersebut terdapat sebuah pendopo yang sangat luas dan asri. 
RM Kristiadi, adalah bungsu dari 4 bersaudara. Di antara mereka hanya dirinya yang memiliki kegemaran di bidang seni, terutama tari. Orang tuanya mendorong RM Kristiadi bertekun dalam kesenian tradisi, meski tidak mengharuskannya hidup dari berkesenian. Orangtua RM Kristiadi sempat heran saat putranya ini tidak melanjutkan studi di bidang seni. RM Kristiadi sendiri pada awalnya tidak meyakini jika tari dapat menanggung kehidupannya kelak. Itu sebabnya, RM Kristiadi selepas SMA tidak memilih melanjutkan studinya di bidang Seni, dan justru memilih bidang ekonomi di Universitas Pembangunan Nasional Veteran. Pilihan ini disesalkan sang ayah. Meskipun tidak mengharuskan anaknya menjadi seniman, namun sang ayah meyakini bahwa menari dan kesenian adalah jalan hidup si bungsu. Dan benarlah apa yang diyakini sang ayah. RM Kristiadi tidak bergairah dalam mendalami ilmu ekonomi, sementara aktifitasnya menari justru tak terbendung. Di tahun ke dua kuliah, akhirnya ia memutuskan untuk kuliah di Jurusan Seni Tari di ISI Yogyakarta pada tahun 1988. Hal ini melegakan sang ayah, karena anaknya akhirnya melanjutkan studi pada bidang yang memang benar-benar dicintainya.

Selain membentuk sanggar-sanggar tari dan kesenian, RM Kristiadi juga kerap diundang menari ke luar negeri sebagai anggota delegasi budaya. Beberapa negara yang telah disinggahi, antara lain Amerika Serikat, Belanda, Spanyol, Itali, Argentina, Colombia, Peru, Chile, Malaysia, Singapura, dan Thailand.

Sejak kecil hingga kuliah, RM Kristiadi dibentuk oleh guru-guru sesungguhnya dalam berkesenian, yaitu Ben Suharto, S.ST., M.A., KRT. Brongtodiningrat, RL. Hanafi Wiharjodikoro, RL. Kintoko Mardowo, RM. Bagong Koesoediardjo, KRT. Soehartono Condroradono, RL. Sasminto Mardawa. Dari guru-gurunya tersebut RM Kristiadi mempelajari pendalaman proses penciptaan, caranya dengan mempelajari keunggulan dari masing-masing guru. Kelak cara ini pun mempengaruhi proses penciptannya, dengan rekan-rekan kerjanya, di TVRI Yogyakarta.

Guru-guru saya itu banyak. Uniknya setiap guru saya pasti bercerita tentang kehebatan guru yang lain... Guru-guru saya tidak pernah menjelek-jelekkan orang, Mas Kris, sing jenenge mas Dinu itu apike ngene iki, nanti saya ke sana, sing jenenge Janadi itu apiknya di sini ini mas, Jadi saya harus meemukan kebaikan dari guru-guru saya. Itu namanya kreatifitas. (wawancara 10 September 2019)

\section{Memulai di Layar Kaca}

RM Kristiadi mulai berkarir di TVRI sejak tahun 1992, dengan jenjang karir yang sangat dasar karena tidak berbekal pendidikan penyiaran. Saat itu TVRI sedang mengalami krisis SDM yang memiliki pengetahuan Budaya Jawa. Pihak TVRI meminta rekomendasi SDM di lingkungan Kepatihan (kantor Kubernur DIY) . Pada saat itu RM Kristiadi sedang berkegiatan di lingkungan Kepatihan. Romo Tirun (RM Tirun Marwito), seorang pengageng di lingkungan Kepatihan sekaligus mentor RM Kristiadi merekomendasikannya untuk bekerja di TVRI karena dianggap memiliki kriteria sebagai SDM muda yang memiliki kecakapan dan pengetahuan tentang seni dan budaya Jawa.

Pertama kali bekerja di lingkungan TVRI, RM Kristiadi belum selesai kuliah di ISI Yogyakarta. Ia pun masih berstatus karyawan kontrak yang bertugas sebagai Floor Director, yaitu seorang yang berperan mengomunikasikan perintah Pengarah Acara dari Control Room ke ruang studio atau floor. Tiga tahun berikutnya, yaitu tahun 1995, barulah RM Kristiadi, yang telah menyandang gelar S.Sn., resmi diangkat sebagai Pegawai Negeri di lingkungan TVRI Stasiun Yogyakarta, dan mendapatkan posisi sebagi Pengarah Acara (setelah mengikuti Pendidikan Latihan Pengarah Acara pada tahun 1995). Pada masa itu RM Kristiadi banyak berkecimpung mengarahkan program-program studio berkaitan dengan Seni Budaya Jawa, sep- 
erti Ketoprak, Karawitan dan Sendratari. Pada tahun 1997 barulah RM Kristiadi mendapatkan penempatan yang sesungguhnya, yaitu pada bagian perencanaan program atau keproduseran.

Pada bagian yang baru ini, RM Kristiadi mendapat tanggung jawab dalam merencanakan sejumlah program yang ditayangkan di TVRI. Program-program yang ditangani tidak lagi sebatas program-program seni tradisi, melainkan juga pengembangan-pengembangannya. Bekerja di stasiun televisi di daerah dengan dana yang tidak sebesar televisi swasta diperlukan sebuah pengembangan program yang super kreatif. Di sini peran produser sebagai perencana atau perancang acara sangat dituntut dan diharapkan.

Di awal menjabat sebagai produser RM Kristiadi mendapat tantangan untuk menghidupkan program dengan format fragmen yang kurang diminati penonton. Program fragmen adalah program terbuka, diisi oleh instansi-instansi Dinas di Yogyakarta dan Jawa Tengah untuk menyampaikan program-program yang mereka miliki. Pengisi acara dari program ini adalah para pegawai instansi yang memiliki kegemaran bermain sandiwara. Program ini dipandang kurang berhasil karena nilai kepemirsaannya rendah, karena dimainkan oleh pemeran-pemeran yang tidak profesional. Hasil dari pengamatan inilah yang menjadi dasar RM Kristiadi kemudian merombak program tersebut dan membidani lahirnya program Obrolan Angkringan.

Obrolan Angkringan sendiri sejatinya justru sebuah Talk Show yang diformat dalam sebuah pertunjukan semi fragmen, dengan unsur-unsur teaterikal yang dibawakan para tokohnya untuk mengilustrasikan tema-tema yang diangkat dalam setiap episodenya.

Secara visual program Obrolan Angkringan ini dibangun atas set gerobak angkringan yang menjual berbagai penganan dan minuman khas (wedang). Angkringan merupakan fenomena yang sangat umum bagi masyarakat Yogyakarta, mudah ditemui di berbagai penjuru kota (bahkan hampir di setiap gang perkampungan).

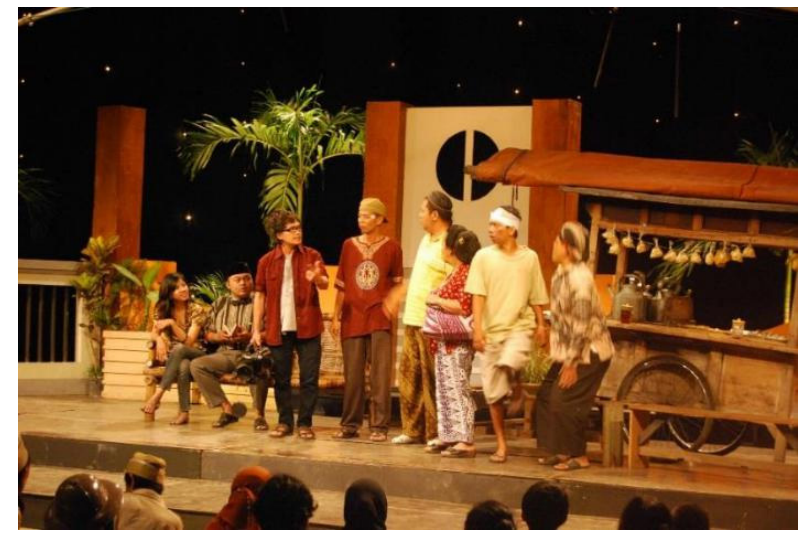

Setting Obrolan Angkring (sumber: fb obrolan angkring)

Warung angkringan pada umumnya buka mulai pukul 18.30 hingga larut malam atau bahkan dinihari (kini tak jarang ditemukan angkringan yang buka siang hari). Ditemani alunan siaran radio, warung ini biasa menjadi ruang bertemu warga untuk melepas lapar atau dahaga, sembari membicarakan berbagai hal aktual yang mereka alami sehari-hari. Suasana ruang berkumpul di warung angkringan merupakan atmosfer keseharian masyarakat Yogyakarta.

Perubahan penting format fragmen menja di Obrolan Angkringan adalah penggunaan pemain tetap dalam setiap episodenya. Seiring perjalanan waktu, program ini berhasil melahirkan pemain-pemain tetap yang semakin berkualitas dan profesional dan mampu mampu meningkatkan awareness penonton terhadap program ini. Beberapa pemain awal program ini Harjono (alm), Heri Dwi Rudi, Hani Rabiyes dan Wisben Antoro.

Khalayak sangat menikmati program ini tanpa dipengaruhi apa pun tema yang dibawakan. Saat ini program achor acara ini adalah Dalijo, Srundeng (Rio Pujangkoro) dan mbok Beruk (Yustiningsih), yang saat ini tidak hanya dikenal di layar kaca, namun menjadi bagian selebritas di masyarakat Yogyakarta. Beberapa pemain muda pun turut meramaikan, seperti Cenil, Trinil, Prawiro, Plentong dan lain-lain. 


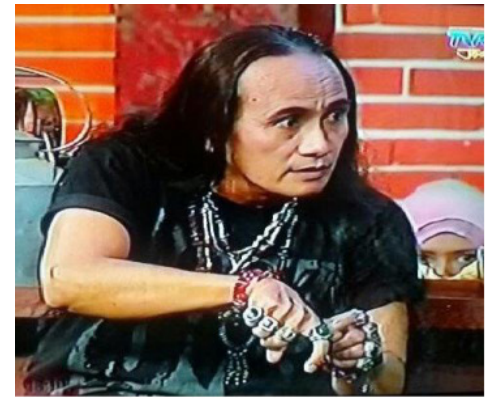

Dalijo

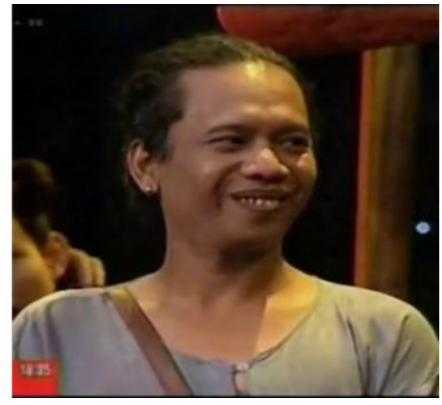

Srundeng

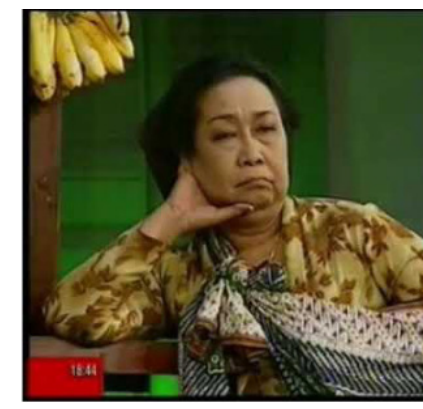

Yu Beruk

Foto 9. Para pemain Obrolan Angkringan

(sumber: Screen capture Youtube TVRI Yogyakarta)

Sebagaimana fragmen, Obrolan Angkringan tetap menjalankan misi menyampaikan informasi dan edukasi dari lembaga pemerintahan, dengan kerap menghadirkan narasumber untuk menyampaikan suatu tema. Dengan demikian fungsi sebagai media informasi dan edukasi tidak hilang, justru diperkuat juga pada sisi hiburannya. Program ini mulai ditayangkan sejak tahun 1997, dan masih mendapat atensi sangat baik hingga saat ini.

Obrolan Angkringan adalah program talk yang menghadirkan narasumber dari lembaga kedinasan di Daerah Istimewa Yogyakarta yang ingin menyosialisasikan program-program pemerntah kepada masyarakat. Hal ini lumrah, dikarenakan TVRI Yogyakarta adalah ruang sosialisasi yang paling mengena di level lokal dan juga memiliki biaya tayang program yang relatif terjangkau untuk lembaga kedinasan di daerah. Bahkan setiap kabupaten memiliki program sendiri demi menjaga eksistensi program yang hendak disajikan kepada masyarakat. Program-program tersebut antara lain Taman Gabusan untuk Kabupaten Bantul, Slemana Sembada untuk Kabupaten Sleman, dan Wayang-Wayang Kertas bagi pemerintah Kota Yogyakarta.

Menguatnya kepemirsaan dan keterlibatan pemerintah yang turut mendanai program-program televisi di TVRI Yogyakarta membuat program-program tersebut eksis. Dari sisi kepemirsaan juga mengantarkan TVRI Yogyakarta selalu berada dalam posisi papan atas dibandingkan TVRI stasiun daerah lain di
Indonesia. Bahkan untuk wilayah Yogyakarta sendiri, TVRI mampu mengalahkan share beberapa Televisi Swasta Nasional.

Selain Obrolan Angkringan dan WayangWayang Kertas yang telah terbukti mencapai usia siaran belasan tahun, RM Kristiadi juga membesut program baru, yaitu Ketoprak Televisi berjudul Beteng Rotterdam, yang ditayangkan dalam 2 session yaitu tahun 2018 dan 2019. Program ini bercerita tentang api perjuangan para abdi dalem dan masyarakat luas yang masih menyala pasca perang Jawa 1830 , setelah Pangeran Diponegoro ditangkap, dipenjara dan diasingkan di Beteng Rotterdam di Makassar.

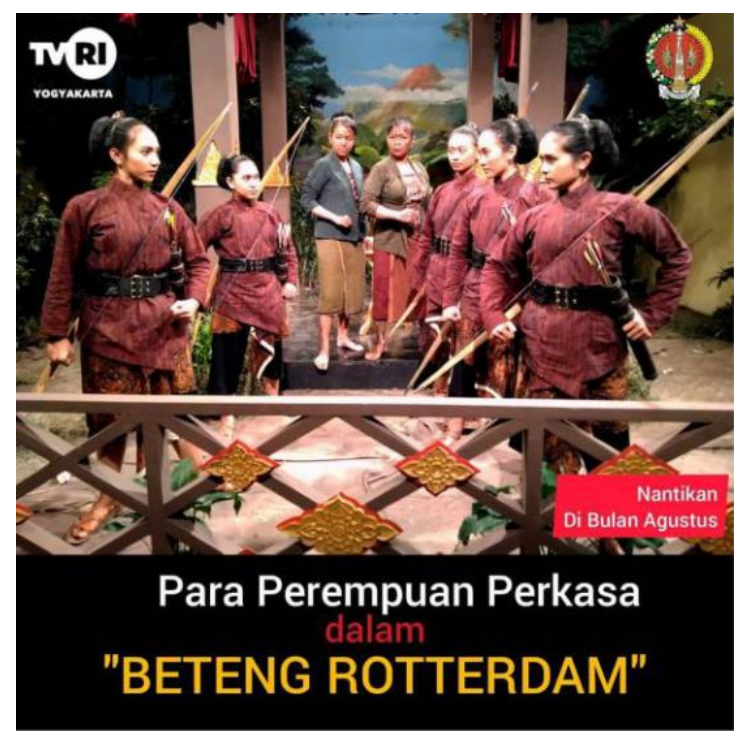

Cover IG TVRI, promosi program Beteng Rotterdam, sangat menonjolkan figurperempuan yang pemberani. (Sumber: IG TVRI Yogyakarta) 
Saat ini Beteng Rotterdam merupakan salah satu program unggulan TVRI Yogyakarta, yang diproduksi dari hibah Dana Istimewa. Program ini dikerjakan dengan sangat ketat, baik secara waktu maupun secara kualitas. Secara materi, cerita Diponegoro berbeda dari ketoprak kebanyakan yang diangkat berdasar kisah babad semata, karena Diponegoro merupakan Pahlawan Nasional yang memiliki dimensi kesejarahan sangat dekat dan menjadi pengetahuan umum. Oleh karenanya, cerita yang disajikan memerlukan riset-riset yang cukup mendalam.

Dalam pertemuannya dengan Gusti Hayu, putri Sri Sultan Hemengku Buwana X yang membidangi media dan pengarsipan di Kraton Yogyakarta, RM Kristiadi mendapatkan tulisan-tulisan Peter Carey, peneliti Belanda yang fokus terhadap sejarah Diponegoro. Selain itu juga Buku Babad Diponegoro karya keluarga Diponegoro, dan History of Java karangan Sir Stamford Rafles. Secara kesejarahan ketiga buku tersebut menjadi acuan dalam riset pengembangan cerita.

Berbagai program yang ditangani oleh RM Kristiadi Walaupun tidak secara khusus membicarakan budaya Jawa, namun program-program tersebut kental sekali dengan seting peristiwa yang lekat dengan memori masyarakat Jawa. Hal ini sejalan dengan perjalanan kreatif RM Kristiadi yang sejak kecil sudah hidup di arena atmosferik atau jagad Jawa.

\section{Upaya Pencarian Jatidiri dalam berkarya}

Masa kecil RM Kristiadi yang sangat sarat dengan nuansa atmosferik Jawa, dengan alunan gamelan yang mengiringinya menari, dipercaya membentuk memori tubuhnya. Memori tubuh ini adalah daya bawah sadar setiap kreator yang mempengaruhi karya-karyanya secara langsung atau pun tidak langsung, yang didapat dari seluruh pengalaman hidupnya.

Manusia kan memiliki memori tubuh, mulai lahir sampai sekarang, saya kalau diminta menciptakan sesuatu yang tidak pernah saya lakukan itu tidak akan keluar-keluar. (wawancara 10 September 2019)
Pengalamannya yang luas ketika kecil dan remaja mampu dielaborasi saat berkarya di panggung televisi. Hal tersebut dapat dilihat dari nuansa karya-karyanya, yang sekalipun bertajuk talk show, namun sangat ringan, komedik dan menghibur pemirsanya.

RM Kristiadi memiliki tiga prinsip dalam mengelola kreatifitasnya, yaitu, yang pertama, membuka diri; ke dua, sabar menanti; dan ke tiga. rela menghormati.

Membuka diri adalah sebuah upaya bagaimana seorang kreator harus mampu menyerap semua hal yang ada di sekitarnya sebagai sumber kreatifitas penciptaan. Semakin banyak hal yang mampu diserap, maka akan semakin banyak kemungkinan kebaruan yang akan dapat diciptakan. Kemudian yang ke dua, Sabar Menanti: seorang kreator tidak boleh buru-buru dalam berproses. Seluruh proses harus berlatih berulang-ulang untk mendapatkan kematangan, terutama dalam mengolah kebaruan.

Formula kreatif ke tiga yang dipegang RM Kristiadi adalah rela menghormat atau melayani; memiliki kerendahan hati. Prinsip ini sejatinya adalah sebuah nilai untuk mau melayani orang-orang yang akan mendukung proses kreatif seorang kreator. Setiap orang memiliki pengalaman sekaligus keterbatasan pengalaman. Keterbatasan pengalaman ini hanya akan dapat diatasi jika kreator mampu melihat potensi orang-orang di sekitarnya, baik senior maupun yunior, yang dapat membantunya dalam mengisi keterbatasan pengalamannya.

RM Kristiadi juga mengatakan bahwa musuh utama seorang kreator adalah sombong. Perasaaan besar diri pada capaian yang pernah dilalui akan membuat seseorang enggan belajar lebih banyak lagi dan cenderung hanya mencopy paste ide-ide yang dimilikinya.

Sabar menanti dalam berposes pun sangat dirasakan saat mengembangkan program Obrolan Angkringan. RM Kristiadi sangat 
menekankan hal ini, terutama dalam berproses dengan pemain dan kru. Hal ini sangat penting karena dia percaya bahwa setiap manusia memiliki potensi kreatif, namun kecepatan masing-masing dalam membuktikannya tidak sama. Ada yang cepat namun ada pula yang lama. Uniknya, yang lama ternyata dapat pula memiliki potensi kreatif yang lebih besar daripada yang cepat. Sebuah proses untuk mendapatkan potensi yang optimal dari sekian banyak potensi yang dimiliki, baik oleh diri sendiri maupun dukungan seluruh tim dalam bekerja, menurut RM Kristiadi, harus dilakukan dengan sabar,.

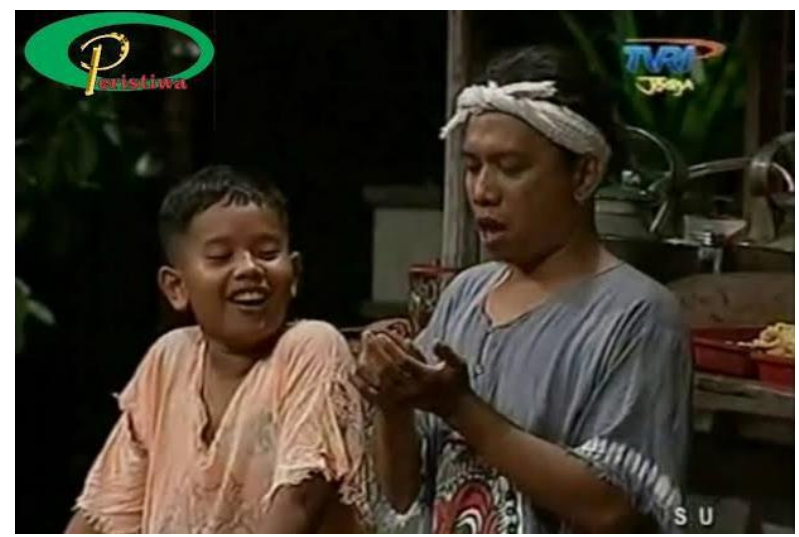

Plentong dan Srundeng di Obrolan Angkringan. (Sumber: Youtube.com Channel TVRI )

Contoh dari implementasi prinsip ini adalah saat ia mengasah Rio Pujangkara, pemeran tokoh Srundeng. Saat tampil pertama kali dalam Obrolan Angkringan Rio hanya mendapatkan porsi seperempat dari yang dicapainya saat ini. RM Kristiadi menaikkan porsi pementasan bagi para pemainnya setahap demi setahap, sesuai dengan kemampuan sang aktor dengan istilah naik kelas, hingga akhirnya menjadi pemain utama.

Srundeng dan Prawiro satu tahun mas. Srundeng itu pernah mutung karena tidak menemukan formnya. Itu kroso, mas. Cuma yang perlu diasah itu kerendahan hatinya. Kalo kerendahan hatinya luntur itu seperti istri kita kalau saat berhubungan tidak ada kerendahan hati, waduh, ora biso orgasme. Yang kita olah itu kan jiwa, mas, Kerendahan hati itu nggak ada ukurannya. (wawancara 6 Oktober 2019)
Hal ini penting, sebab jika memaksakan sebuat target, maka hal tersebut akan membuat aktor tampil buruk, dan bahkan dapat mematikan bakat keaktorannya.

Seorang sutradara itu tidak elok membunuh pemain di atas panggung. Jadi si sutradara harus menghormati pemain agar tidak membunuh di atas panggung. Jadi jika masih setengah porsi jangan dipaksa, kalo tidak mati artinya jelek. Misal, Antawirya. Selama sekian tahun saya menemani dia, misal kowe ra sah ngomong, kowe dadi iki, apik, tambahi. Istilah saya, naik kelas. (wawancara 20 September 2019)

Hal ini menurut RM Kristiadis a ng at penting. Karena selama ini, dalam masyarakat pendidikan, keaktoran lebih berpusat $\mathrm{p}$ a $\mathrm{d}$ a keaktoran panggung. Padahal keaktoran di televisisangat berbeda dengan keaktoran di panggung. Ia meyakini, panggung televisi adalah panggung keaktoran yang berbeda dengan teater maupun teater tradisional. Seorang aktor teater dapat tampil megah dan gagah di panggung teater namun belum tentu dapat melakukan hal yang sama di layar televisi, demikian pula sebaliknya.

Walaupun RM Kristiadi memiliki latar belakang sebagai penari, namun RM Kristiadi menyadari benar, bahwa inti dari pertunjukan adalah keaktoran. Hal tersebut kemudian diamini RM Kristiadi seturut dengan pemahaman dari para guru beliau.

Guru-guru sepuh selalu mengatakan ada penari yang tariannya bagus tapi tidak bisa jadi wayang. Dalam analisa saya sekarang, wayang itu berarti keaktoran yang berhubung dengan karakter. Guru tari sepuh selalu mencontohkan penari-penari hebat seperti Atmo Netyo, Suryobrongto, Brongtodiningrat, Atmosastro yang punya teknik tari bagus dan kejiwaan yang bagus juga. Kejiwaan itu adalah teknik peran atau keaktoran. .... Lalu penyutradaraan dalam tari klasik yang heroik, tiba-tiba lemah lembut, tiba-tiba komedi adalah bukti bahwa ada drama yang kuat yang harus dihadirkan. (wawancara 20 Oktober) 
Namun demikain, dalam pengalamannya di Televisi, RM Kristiadi berpandangan bahwa keaktoran dibangun berdasar pada energi pancaran dari wajah.

Pemain panggung itu energinya di tubuh, berbeda dengan pemain TV yang energinya di close up. Orang panggung kesulitan menyalurkan energinya lewat muka atau wajahnya, gerakannya kecil tapi di close up. (wawancara 10 september 2019)

Inilah yang membuat kelahiran aktor televisi yang baik jadi harus memerlukan waktu berproses lebih panjang. Kesadaran ini sangat membantu RM Kristiadi dalam melahirkan aktor-aktor handal dari program besutannya di TVRI yang seringkali berupa program-program televisi yang diangkat dari ide panggung pertunjukan.

Rela menghormat dalam proses kreatif juga dicontohkan RM Kristiadi saat ia harus membuat program dengan tema yang dirinya belum pernah bersentuhan, misalnya narkoba atau prostitusi. Rela menghormat yang dimaksud RM Kristiadi, adalah bagaimana seorang kreator harus menghormat setiap orang yang ada di sekitarnya, sekalipun mungkin adalah bawahannya. Hal ini

Hal ini benar-benar dirasakan RM Kristiadi saat dirinya mentok menarasikan tentang narkoba dalam naskahnya. Pada akhirya, dengan kerendahan hati, ia membuka diri menerima nasihat mengenai narkoba tersebut dari seeseorang yang mengetahui hal tersebut, termasuk dengan kru atau bawahan, pemainnya atau orang lain yang mengerti atau punya pengalaman tentang tema tersebut. Ini sangat membantu pengadeganan dalam naskah-naskah episodenya Beteng Rotterdam, yang di dalamnya juga menceritakan tentang perdagangan ganja pada masanya. Kerelaan menghormai seluruh orang yang ada di sekitarnya tanpa memandang status membuat kreator bertemu dengan lebih banyak guru-guru baru. Hal demikian seringkali pula dialami oleh Kristiadi dalam mengelola potensi kreatifnya.

\section{Jagad Jawa dalam Karya RM Kristiadi}

Suasana Atmosferik dalam lingkungan budaya Jawa di kraton sangat mempengaruhi ketajaman RM Kristiadi mengenai Jagad Jawa. Jagad Jawa menurutnya terdiri atas tiga tingkatan. Tingkatan pertama adalah Memori Tubuh, kemudian Kerangka Fantasi, dan tingkatan ketiga berkait dengan Daya Kritis yang mengolah kerangka fantasi menjadi kebaruan berikutnya

Memori tubuh adalah bekal yang dibawa oleh setiap manusia. Sejak lahir manusia menyimpan seluruh pengalaman hidupnya tanpa dia sendiri sadari. Memori tubuh RM Kristiadi ini terejawantahkan. Karya-karya ciptaannya tidak lepas dari pengalaman-pengalaman yang pernah diterimannya. RM Kristiadi mengungkapkan bahwa dia mampu berkreasi mengenai hal-hal yang berkait dengan pengalamannya sejak muda, namun untuk hal-hal yang tidak pernah bersentuhan sebelumnya dia selalu mengalami kesulitan, sehingga membutuhkan bantuan orang lain.

Kerangka fantasi adalah sebuah cara pandang seniman yang diperoleh dari sebuah pengalaman melihat sesuatu yang baik atau sesuatu yang dianggap baik, atau memiliki standar tertentu. Seorang kreator tentu memiliki patokan-patokan dalam melihat kualitas suatu karya. Sebagai pengkarya, seniman akan mematok hasil karyanya berdasar patokan-patokan tersebut, yang bisa saja berdasar karya-karya yang dikagumi sebelumnya. Dengan demikian kerangka fantasi menyerupai suatu ekspektasi.

Kerangka fantasi sendiri sebetulnya tidak hanya domain kreator. Masyarakat sebagai penonton juga memiliki kerangka fantasinya sendiri. Dalam masyarakat kerangka fantasi ini diukur dari pengalaman seni yang ada dalam masyarakat itu sendiri, Dalam melihat baik/ tidaknya sebuah karya, jika penonton harus jadi ukurannya, misalnya dalam seni-seni populer, maka mau/tidak mau kerangka fantasi pengkarya ataupun penonton haruslah sama.

Hal ini dilakukan Kristiadi dalam membangun konsep program-program besutannya. 
Dalam Obrolan Angkringan, Kerangka fantasi ini dihadirkan tidak dengan narasi deskriptif yang disampaikan oleh pelakunya, atau bantuan tampilan grafis yang besar dan menonjol, namun dengan menghadirkan gerobak angkring sebagai set utama. Baik kreator maupun masyarakat Yogyakarta, memiliki kesamaan fantasi tentang suasana keseharian berkumpul bersama untuk membicarakan hal-hal sehari-hari secara hangat dan akrab dalam masyarakat Yogyakarta (seperti suasana gojekan, membicarakan isu yang hangat mulai dapur hingga politik), dengan aroma kopi dan jahe, maupun alunan suara tembang dari radio. Dalam kerangka fantasi ini kesan menjadi lebih kuat daripada pesan. Dalam kesan yang kuat pesan-pesan yang akan dsampaikan dalam program akan lebih mudah diterima oleh penonton.

Kesan itu lebih kuat daripada pesan. Misalnya kata sedih dalam membuat adegan menangis itu gampang, tapi membuat orang lain menangis melihat adegan sedih yang kita buat itu lebih sulit. (wawancara 10 september 2019)

Demikian juga mengenai mengangkat kepahlawanan Diponegoro dalam Beteng Rotterdam. Hal ini pun tak lepas dari kerangka fantasi masyarakat Yogyakarta tentang epik kepahlawanan yang dekat dengan mereka. Kedekatan seperti ini secara tidak disadari telah terstruktur dalam ingatan kolektif masyarakat Yogyakarta dalam membangun konsep kepahlawanan yang ada dalam pikiran mereka. Diponegoro adalah pahlawan yang berasal dari Yogyakarta, merupakan keturunan dan leluhur dari Keraton Yogyakarta, yang hingga saat ini peneninggalannya masih dapat dijumpai oleh masyarakat Yogyakarta di museum Pangeran Diponegoro, Tegalrejo.

Secara lebih luas, kerangka fantasi ini sebenarnya tidak berdasar atas pengalaman yang ada di lingkungan saja. Dalam industri yang lebih besar, RM Kristiadi juga menyadari bahwa para kapitalis memanfaatkanya untuk menguasai pasar.
Dalam kapitalisme, fantasi-fantasi dihembuskan untuk menyerang bawah sadar masyarakat atas suatu kebenaran-keenaran yang mengontrol realitas sesuai dengan yang akan mereka hadirkan. Itu sebabnya, bagaimana kemudian masyarakat lebih mengamini kecantikan ala Barbie sebagai sebuah kebenaran, daripada kecantikan warisan leluhur. (wawancara 10 September 2019)

Oleh karenanya kerangka fantasi ini perlu dipicu untuk dapat kembali hadir dan aktual dierima oleh masyarakatnya. Kerangka fantasi ini bekerja tidak hanya dalam konsep besarnya saja, namun secara operasional dibangun menjadi dasar elemen-elemen program mulai dari cerita, seting, tokoh, audio dan sebagainya.

Jagad Jawa menurut RM Kristiadi merupakan sebuah peluang untuk menghadirkan kembali kerangka fantasi dalam masyarakat Yogyakarta. Jagad Jawa masih memiliki peluang yang cukup besar karena dalam masyarakat Jawa, suasana dan nuansa Jawa masih relatif dapat ditemukan dalam pola kehidupan sehari-hari, antara lain dalam bahasa maupun tata cara organisasi dan kegiatan kemasyarakatan. Pendekatan dengan kerangka fantasi ini merupakan sebuah formula bagi sebuah program untuk mendapatkan kepemirsaan yang baik.

Cara pandang ketiga mengenai penghadiran Jagad Jawa menurut RM Kristiadi adalah dengan menghadirkan daya kritis dari kerangka fantasi yang telah umum di masyarakat, sehingga dianggap kaprah. Hidup dalam jagad Jawa selama hayat melahirkan pertanyaan-pertanyaan dalam diri yang semakin menagih jawaban. Hal tersebut berlaku pada setiap generasi. Hal ini pula yang kemudian menjadi pemikiran RM Kristiadi setelah eksistensinya teruji, saat masyarakat menerima karya-karya yang dibesut berhasil menghadirkan kerangka fantasi yang sama antara rancangan program dengan imajinasi pemirsa. Maka dari kerangka fantasi yang sama tentu saja memerlukan kebaruan-kebaruan selanjutnya.

Kebaruan yang hadir tidak bisa lepas 
dari kerangka fantasi yang sudah ada, namun tentu tidak boleh sama. Kesamaan-kesamaan yang tereproduksi akan menunjukkan stagnasi dan ketidakkreatifan pencipta. Oleh karenanya kerangka fantasi perlu dipertajam dalam kerangka-kerangka penajaman melalui daya kritis. Hal ini dilakukan Kristiadi dalam Ketoprak Televisi Beteng Rotterdam.

Beteng Rotterdam sesungguhnya merupakan buah daya kritis pemikiran RM Kristiadi selama ini. Ia berpendapat bahwa wayang sebagai seni tutur paling utama di dalam khasanah jagad penceritaan Jawa selama ini hanya beredar dalam 3 domain utama yaitu laki-laki, kekuasaan dan dunia orang dewasa.

Dalam kisah-kisah wayang, sebagian besar narasi yang dimunculkan adalah narasi laki-laki dan laki-laki jugalah yang menjadi pusat penceritaan, baik dalam konflik utama hingga sebagian besar konflik-konflik sayapnya.

Hal ini membuat perempuan tidak memiliki porsi penceritaan yang memadai dalam, bahkan tidak hanya wayang, namun juga kisah-kisah pada budaya Jawa, Selain itu keberadaan tokoh perempuan seringkali juga ditampilkan secara stereotipe sebagai peran yang cengeng dan atau dihadirkan untuk memperlihatkan kemolekan tubuhnya. Dalam hal ini Kristiadi menyampaikan bagaimana misalnya saat ini tarian itu justru dianggap sebagai domain perempuan, sebagai kekaprahan saat ini. Padahal menurut memori tubuh yang dimilikinya, bahwa dalam tradisi di Yogya, tarian itu sebetulnya adalah gagah, sangat maskulin.

Nah guru tari saya yang alusan itu, iu kebanyakan adalah pendekar pencak silat, jadi tidak ada tari yang keperempuan-perempuanan. Jadi guru tari saya itu tipe RL Mardowo, itu pendekar pencak silat, Romo Janadi Wiharjodikoro Kamto, Romo Yuan, Brongtodiningrat, itukan pendekar-pendekar pencak silat. Bayangkan pendekar pencak silat lalu menari keperempuan-perempuanan, kemayu itu kan nggak mungkin. ..... Romo

Hari itu pendekar Krisna Murti, jadi tidak mungkin pendekar Krisna Murti yang jadi penjaga pintu depan kraton Yogyakarta, lalu narinya ngondek, itu kan nggak mungkin. Itu yang coba saya tawarkan pada generasi di bawah saya. (wawancara 6 Oktober 2019)

Yang ke dua adalah domain orang dewasa. Dalam kisah-kisah budaya Jawa sangat kurang ditemukan kehadiran tokoh anak-anak. Hampir tidak ada dalam tokoh-tokoh pewayangan, jikalau ada, pun hanya diceritakan mengenai kisah kelahiran yang seterusnya dibicarakan dalam domain peralihan kekuasaan, artinya membahas isu-isu perihal dunia orang dewasa.

Betara guru bersenggama di atas lembu, kromo tuh jadi Anoman. Sengkuni duburnya... ja disobek-sobek kuku ponconoko oleh Werkudara, itu kan domain kekerasan. Domainnya orang dewasa. Apa pantes didengarkan anak-anak. Tapi untuk nguri-uri, bagaimana itu disampaikan pada anak-anak? (wawancara 10 September 2019)

Dan yang ke tiga, domain penguasa. Dalam pewayangan Jawa, rakyat kecil tidak dihadirkan. Seluruh tokoh yang muncul dalam kisah pewayangan selalu tentang para penguasa yang diwakili oleh bangsawan maupun para dewata. Beberapa tokoh biasa yangmuncul, seperti anak sais kereta misalnya, pada akhirnya diketahui adalah juga keturunan bangsawan. Bahkan jika panakawan dianggap sebagai representasi rakyat kecil, maka itu pun tetap harus dihadirkan dalam framing Semar sebagai titisan dewa.

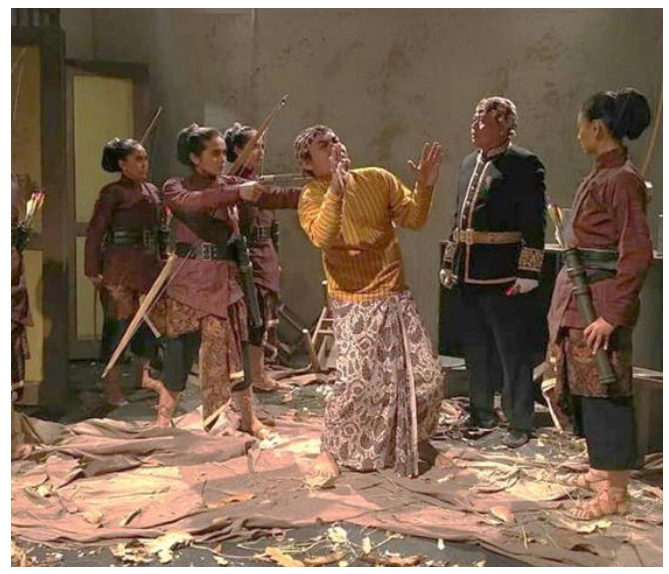

Cover IG TVRI, adegan Ketoprak Televisi Beteng Rotterdam, sangat menonjolkan figur perempuan yang pemberani. (Sumber: IG TVRI Yogyakarta) 
Dalam pelakonan Beteng Rotterdam, setidaknya dua dari ketiga domain tersebut diantitesakan. Pertama, sebagai tinjauan kritis terhadap domain laki-laki, RM Kristiadi menempatkan para tokoh perempuan sebagai sentral penceritaan dalam lakon Beteng Rotterdam. Tidak hanya peran ketokohan dalam konflik, dari segi jumlah pemeran Perempuan pun diangkat lebih banyak. Selain itu RM Kristiadi menghadirkannya dalam karakter perempuan-perempuan yang perkasa, cerdas dan trengginas, jauh dari stilisasi pada pertunjukan tradisi lainnya yang ditampilkan manja dan cengeng, atau menonjolkan kecantikan atau keelokan tubuhnya saja. Yang ke dua, RM Kristiadi juga menekankan tinjauan kritis terhadap domain penguasa. Dalam Beteng Rotterdam, terdapat tokoh bangaan yang muncul sebagai anchor dari alur cerita yang dibawakan, namun demikian, plot dari keseluruhan cerita lebih banyak menceritakan perjuangan rakyat jelata, pengikut sang Pangeran dalam menunjukkan kecintaannya terhadap Pangeran dan perjuangan yang dicita-citakan.

Satu tinjauan kritis yang belum dapat dihadirkan dalam kisah Beteng Rotterdam adalah mengenai domain untuk anak-anak. RM Kristiadi saat ini sedang mengupayakan bagaimana caranya agar tokoh dan domain anak-anak dapat menyeruak masuk dalam kisah Beteng Rotterdam pada session 3 tahun 2020 .

Penghadiran daya kritis terhadap kerangka visual ini disebut juga oleh RM Kristiadi sebagai pemikiran dekonstruktif, yaitu sebuah pemikiran yang mempertanyakan kembali pola-pola lama yang telah diamini dalam upayanya menghadirkan kebaruan. Pemikiran dekonstruktif ini tidak hanya pada ranah konten, dengan target meraih kepemirsaan muda. Dalam format sajian di televisi yang saat ini berhenti sebagai pertunjukan panggung yang dilayarkacakan, Beteng Rotterdam dirombak sebagai format ketoprak televisi, yang memiliki pendekatan scene. Jika biasanya pertunjukan ketoprak hadir dalam 8 adegan, maka dalam Beteng Rotterdam dihadirkan menjadi 20 scene setiap episodenya, dengan format sinema televisi, sehingga memecah persoalan rendahnya minat menonton ketoprak.

Waktu itu dekonstruksinya seperti itu, jadi dekonstruksi itu juga pelan-pelan. Upamane ketoprak kok 20 scene di studio, itu dekonstruksi temanteman di TVRI. (wawancara 20 September 2019)

Mendekonstruksi pola kerja yang bertahun-tahun menjadi pola kerja program ketoprak di TVRI, membawa dampak yang baik, membuat program menjadi menarik dan mendapat kepemirsaan yang lebih baik dari session sebelumnya di tahun 2018, dan mendapatkan target kepemirsaanya, yaitu generasi muda.

Selain itu, dari sisi pengadeganan dan keaktoran, RM Kristiadi menerapkan, bahwa setiap pemain harus memahami setiap latar belakang karakter yang dimainkan dengan ikut membaca referensi-referensi yang digunakan dalam membuat naskah. Dengan sistem ini pemain dapat mengekspresikan kerakternya secara lebih luwes dan cepat. Pada tataran ini, dengan metode produksi seperti ini, justru dapat tetap menerapkan gaya atau kerangka fantasi pementasan ketoprak yang sesungguhnya yang dipindahwahanakan sebagai tontonan televisi.

Jadi, naskah sudah jadi kita kan. Naskah bisa berubah, bisa, nah gak bisa begini mas? Itu yang saya nanti jadi begini... artinya saya punya pemain cerdas. Kalo naskah hanya seperti yang saya tulis, itu saya tidak perlu pemain cerdas. Saya butuh anak SMA saja, nggak usah baca. Di Beteng Rotterdam saya belanja buku mas, saya bagikan pada kreatif saya. Jadi mereka menawar. Mas didik mas Robert itu kan skenografer, itu menawar. Jadi semuanya harus cerdas. Jadi kecerdasan banyak orang itu kecerdasan yang luar biasa. (wawancara 20 September 2019)

Pola kritis, yang menurut RM Kristiadi sebagai sebuah proses dokontruksi kreatif, ini 
antara lain juga tampak pada sajian Obrolan Angkringan. Dalam program ini para pemain harus tampil terbalik. Para pemain harus menanggalkan keintelekannya dan harus berperan menjadi orang 'goblok'.

Kudu angle dari hal yang kamu tidak boleh S1. Itukan dekonstruksi bagi teman2 dan narasumbernya. Sampai Sultan pun diwawancarai dengana angle yang berbeda. Dan pertanyaannya juga harus goblok. Ada narsum yang protes presenternya TV itu pertanyaannya goblok-goblok. Memang kudu goblok. (wawancara 20 Oktober 2019)

Diksi yang dipilih tidak boleh diksi-diksi yang menunjukkan keterpelajaran para pelaku. Dalam hal inilah keaktoran para pelaku benar-benar teruji. Memerankan tokoh kebanyakan masyarakat yang latar belakangnya berbeda dari latar belakang para pelaku.

Dengan berperan seperti itu, maka pertanyaan-pertanyaan yang diajukan para pemain kepada narasumber dapat keluar lebih spontan, dan mendasar. Hal ini kadang terjadi juga pada narasumber yang dihadirkan. Para narasumber yang menghadapi pertanyaan-pertanyaan spontan kemudian harus mendekonstruksi pola pikirnya yang selama ini terlalu sistematis dalam merancang program, harus menyampaikan kepada tataran-tataran praktis yang dipahami masyarakat kebanyakan.

Pada awalnya upaya dekonstruksi kreatif ini sulit diterima, dan para pemain mendapat stigma, bahwa pertanyaan-pertanyaan yang diajukan adalah pertanyaan yang bodoh. Namundemikian sebagian yang lain dapat menerima, bahkan dalam suatukesempatan berpentas off air di pendopo Kepatihan Yogyakarta, Ngarsa Dalem (Sri Sultan Hamengku Buwono $\mathrm{X}$ ) bersedia turut berperan dalam acara Obrolan Angkringan dan bahkan turut berperan larut ndagel (melawak) dengan para pemain lainnya, walaupun sebelumnya hal tersebut bertentangan dengan aturan keprotokoleran yang ada. Bentuk dekonstruksi lain dalam Obrolan Angkringan adalah bentuk dagelan yang dinaskahkan, diarahkan (direct). RM Kristiadi mengatakan, bahwa saat itu belum umum format dagelan panggung tapi disutradarai.

Selain kerangka fantasi, RM Kristiadi membangun keberhasilan perancangan program-program besutannya dengan menempatkan prinsip letupan titik-titik api. Titik api adalah simpul-simpul yang hadir dalam alur penceritaan, hadir dalam setiap scene dan dirancang sebagai letusan dramatik yang direncanakan untuk menahan pemirsa tidak meninggalkan program yang ditontonnya. Bentuktitik api ini dapat berbeda-beda,tergantung jenis programnya. Untuk komedi dapat berupa lelucon-lelucon yang spontan dan natural, untuk drama dapat berupa konflik-konflik yang terus berkembang. Namun titik api tidak hanya disiapkan untuk pemirsa saja. Titik api juga dipersiapkan bagi pemeran. Saat pemeran menemukan titik api dalam sebuah alur, seringkali keluar sesuatu yang diistilahkan RM Kristiadi sebagai energi cadangan. RM Kristiadi mencontohkan, misalnya improvisasi menghadirkan tokoh tambahan yang tidak disangka, sehingga pemeran harus memainkan spontanitas-spontanitas yang mengejutkan pula untuk merespon hal tersebut.

Titik api itu sesuatu yang keluar secara spontan, membakar pemain melewati batas-batas kemampuannya karena suatu hal-hal yang tidak diduga sebelumnya. (wawancara 20 Oktober 2019)

Dalam terciptanya titik api-titik api ini lah, secara internal kemudian setiap pemain serta kru akan tergiring dalam suasana emosional dalam memainkan perannya.

Lalu, titik api itu gunanya, agar informasi itu berhasil sampai pada mereka, pada jiwa mereka. Itu kan sepert daya pikat. Titik api itu daya pikat agar informasinya ke tempat kita sampai. Misal informasi tentang perempuan itu harus menguasai politik, dengan cara humor, 
Kotoprak Beteng Rotterdam, dengan tari itu bisa. (wawancara 6 oktober 2019)

Suasana emosional yang kemudian dalam diksi RM Kristiadi ini disebut mBojo atau berjodoh atau lebih ekstrim bersenggama di ruang emosi yang sangat intim di ruang kreatif.

Dia tidak perlu mengatakan pun kita sudah tahu. Istilahe mbojo. Nek neng panggung mbojo itu prosesnya lama (bisa lama bisa cepat). Jadi kalau Ari Purnomo karo Dalijo tidak kangsenan biso apik, mergane wis mbojo, mbojo itu kita ciptakan. (wawancara 6 Oktober 2019)

Mbojo tidak hanya diterapkan sebagai satu titik api di layar, namun di ruang kreatif. Ia mencontohkan beberapa rekan kerjanya yang sangat memahami keinginannya dalam mengeksekusi program, misalnya Robert Karhono, staf tata artistik, yang telah memahami konsep-konsep tata artistik RM Kristiadi sebaai produser, dan Anggar Wardhananti pengarah acara.

Robert dibidang dekor itu (dengan saya), itu mbojo mas. Saya pesan persneleng 1 dia sudah mancal persneleng 4. Itu mungkin karena seleranya tidak disetel sudah jadi 1.... Mbak Anggar, pengarah acaranya, nggak latihan, cuma dengan treatment itu ooo gini itu gayane nanti ngene, gaya dramatike pedot di sini, itu sudah tahu mas, saya juga tahu, Anggar itu kalau saya begini dia akan begini, itu karena mbojo mas. Pola-polanya sudah mbojo. (wawancara 6 Oktober 2019)

Titik api menjadi bagian penting dalam mencapai tidak hanya capaian cerita, namun dalam setiap eleman kerja yang ada, seperti artistik, editing, casting dan sebagainya. Dengan demikian apa yang bagus di layar, tidak hanya terlihat dari jalannya cerita, namun juga setiap elemenyang terlihat dilayarsepanjang durasi. Hal ini memberikan magnet luar biasa dalam mengikat penonton pada program yang kemudian disaksikan.

\section{Kesimpulan}

RM Kristiadi adalah seorang kreator yang lahir dan besar di lingkungan Kraton Yogyakarta. Suasana Kejawaan yang dirasakan sebagai ruang atmosferik sejak kecil membawanya akrab dengan kegiatan seni dan budaya, baik tari, lawak maupun teater. Hal ini pula selanjutnya yang membawanya mempelajari ilmu seni tradisi secara lebih mendalam. Karirnya di TVRI tidak lepas dari pengalamannya berkesenian sejak masa kecil. Aura Jagad Jawa dalam program TVRI dapat dirasakan dari pengaruh sentuhan rencangan RM Kristiadi dalam periode setelah tahun 1995.

Obrolan Angkringan adalah sebuah program yang sejak awal ditangani oleh RM Kristiadi, sangat kental menggangkat konsep Kerangka Fantasi masyarakat Yogyakarta yang diimplementasikan menurut elemen-elemen setting yang kuat. Antara lain menggunakan simbol-simbol yang diakui sebagai milik masyarakat Yogyakarta, yaitu gerobak angkring yang membawa kerangka fantasi yang sama antara pencipta dan penonton.

Metode pengembangan kreatifitas RM Kristiadi berpijak pada kesadaran membuka diri, sabar menanti dan rendah hari. Konsep ini adalah konsep pelepasan, di mana setelah seluruh tahapan kerja perencanaan dievaluasi dan direfleksi, pada akhirnya akan muncul perspektif baru dalam melihat karya-karya yang telah ditelurkan.

Dari proses yang dilakukan kemudian akan menghasilkan dua hal, pertama adalah menghasilkan kritik atas capaian terdahulu, dengan pendalaman-pendalaman baru dan di sisi lain dengan demikian juga menghasilkan kebaruan-kebaruan dalam penciptaan. Kritik ini disebut sebagai daya kritis.

Daya kritis ini diejawantahkan dalam karya-karyanya, yaitu Beteng Rotterdam dan Obrolan Angkringan. Pada Beteng Rotterdam, RM Kristiadi menghadirkan kritiknya mengenai paradigma pertunjukan Jawa yang sebelumnya 
banyak berpatron pada kaum penguasa, laki-laki dan orang-orang dewasa. Dalam Beteng Rotterdam, RM Kristiadi memunculkan konflik-konflik di antara abdi dalem, dan memberikan porsi besar tentang konflik tokoh-tokoh perempuan dalam ceritanya. Sedangkan dalam program Obrolan Angkringan daya kritis dihadirkan dalam penerapan pola pertunjukan dagelan yang dinaskahkan dan disutradarai, berbeda dengan yang sebelumnya dilakukan. Lebih jauh daya kritis yang melampai kerangka fantasi ini pada nyatanya juga memberi peluang bagi pemain untuk menjadi lebih cerdas. Pemeran dipacu untuk mengenal betul karakternya, sehingga dalam proses produksi pemeran memiliki posisi yang setara dengan perancang dan sutradara dalam menawarkan kepemeranannya. Daya kritis ini lahir tidak lepas dari pengalamannya meninba ilmu dan memperdalam ilmu dari guru-gurunya serta prosesnya dalam berkesenian.

Hal ini tak lepas, dari pengetahuan dan pengalamannya terlibat dalam pertunjukan tradisi di lingkungan Kraton Yogyakarta yang lebih egaliter mengenai gender maupun status sosial, namun dalam dunia pertunjukan saat ini justru terdistorsi. Selain itu ajaran-ajaran para guru juga sangat menjadi ingatannya dan menjadi pertimbangannya dalam mengelola proses kreatif.

Diharapkan penelitian ini dapat dilanjutkan untuk menukik lebih dalam melihat secara langsung proses berkarya RM Kristiadi secara penuh. Pendekatan observasional bisa menjadi metode yang lebih lengkap dalam menangkap dan memahami proses kreatif RM Kristiadi.

\section{Kepustakaan}

Burhan Bungin, 2012, Penelitian Kualitatif: edisi kedua, Jakarta: Penerbit Kencana

Candra, NRA, 2014, Analisis Ide Kreatif Kristiadi sebagai Sutradara Obrolan Angkringan Episode Gara-Gara Facebook TVRI Yogyakarta, Capture vol 5 no 2 Juli 2014.
Certeau, Michel de, 1984, The Practic of Everyday Life, University of California Press.

Darmoko, 2002, Ruwatan: Upacara Pebebasan Malapetaka Tinjauan Sosiokultural Masyarakat Jawa, Makara, Jurnal Sosial Humaniora Vol 6, no 1, Juni 2002

Dwi Astuti, 2014, Pangkur Jenggleng AyomAyem Di Tvri Yogyakarta: Suatu Tinjauan Penyajian Karawitan, Skripsi Jurusan karawitan ISI Yogyakarta.

Johnson, Kathy Avrich, 2002, Development and Other Chalanges, A Produser Handbook, Summer Publisher.

Kellison, Chatrine, 2006, Producing For TV and Film: A Real-World Approach, Focal Press.

Misbach Yusa Biran, 2006, Teknik Menulis Skenario Film Cerita, Jakarta: Pustaka Jaya

Morissan, 2013, Manajemen Media Penyiaran, Jakarta: Kencana Media

Pratista, Himawan, 2008, Memahami Film, Yogyakarta: Homerian Pustaka

Rusman Latief, dkk, 2017, Menjadi Produser Televisi, Jakarta: Penerbit Kencana

Sumantri Raharjo, 2011, Komodifikasi Budaya lokal dalam Televisi (studi Wacana Kritis komodifikasi Pangkur Jenggleng TVRI Yogyakarta, tesis S-2 FISIP UNS

Widhi Nugroho, 2018, Proses Kreatif Edie Cahyono dalam Penciptaan film Siti, Capture: JSMR ISI Surakarta. 